\title{
THE DECLINING STRUCTURAL LIQUIDITY DEFICIT: CHALLENGES AND POSSIBLE SOLUTIONS
}

\author{
V.Morgunov
}

The structural liquidity deficit in Russia's banking sector is on the decline, and it will certainly continue to go down over the course of 2016. This phenomenon is going to make it difficult for the Bank of Russia to implement its interest rate policy in the regime of a symmetric interest rate corridor. It is possible and feasible for the RFCB to implement measures designed to maintain a structural liquidity deficit and achieve the practical target of its lending policy - to ensure that short-term money market rates remain close to the key policy rates.

The ongoing structural liquidity deficit reduction ${ }^{1}$ in the banking sector and the possibility of a structural liquidity surplus have significantly changed the conditions for the Bank of Russia' monetary policy and made much more difficult its task of steering money market interest rates.

In 2015, the greatest input in the structural liquidity deficit reduction was made by the altered parameters of the fiscal and tax policies: the diminishing residuals in the general government accounts with the Bank of Russia added liquidity to the banking sector in the amount of almost Rb 3.1 trillion $^{2}$. The shrinkage of cash in circulation added Rb 0.5 trillion, forex interventions about $\mathrm{Rb} 0.4$ trillion, and the regulation by the Bank of Russia of the required minimum reserves of credit institutions - $\mathrm{Rb} 0.1$ trillion. Thus, in 2015, due to the effects of the various factors that affect liquidity, the structural liquidity deficit shrank by Rb 4.1 trillion. In this connection, the Bank of Russia reduced the volume of liquidity supplied to the banking sector by Rb 3.6 trillion. The residuals in the correspondent accounts of credit institutions at the Bank of Russia increased accordingly.

In early 2016, the process of structural liquidity deficit decline continued and gained momentum. Over January and the first 20 days of February 2016, as a result of the movement of residuals in the general government accounts with the Bank of Russia, liquidity increased by Rb 1.2 trillion, while the shrinkage of the cash in circulation index pushed it up by another $\mathrm{Rb} 0.3$ trillion. On the whole, by 20 February 2016, due to the effects of autonomous liquidity factors, the structural liquidity deficit had shrunk by Rb 1.5 trillion, followed by a shrinkage of the banking sector's debt to the Bank of Russia.

So, what are the prospects for the structural liquidity deficit's behavior in 2016? The law on the federal budget for 2016 envisages, with regard to the sources of funding to be used for covering the federal budget deficit, that the amount of residuals in the federal budget accounts should be altered (reduced) by Rb 2.3 trillion. Half of this funding has already been implemented. Over the next few months, the rest of this sum will also be spent. Besides,

1 For more details on structural liquidity, see, e.g., Morgunov V.I. Management of the Banking Sector's Liquidity and the Short-term Money Market Interest Rate. - M.: Delo Publishing House, RANEPA. 2015.

2 The liquidity behavior indices are calculated by the author on the basis of data on factors that affect liquidity, released by the Bank of Russia, see http://www.cbr.ru/statistics/?Prtid=flikvid 
as the price of oil is expected to stay below $\$ 50$ per barrel (the planned federal budget target), it will be necessary to introduce alterations to the federal budget law with a view towards an upward adjustment of that source of funding earmarked for covering the federal budget deficit. We estimate that at some point during Q3 2016, the structural liquidity deficit in the banking sector will give way to a surplus.

The existence of a structural liquidity surplus will make it problematic for the Bank of Russia to manage the short-term money market interest rate and to keep it hovering near the key rate. It is in this respect that the structural liquidity surplus differs from the structural deficit; the latter, as is well known, creates more favorable conditions for positioning the short-term money market interest rate near the middle of the interest rate corridor (the key rate), because large quantities of liquidity are supplied to the banking sectory at a rate that equals the key rate or is close to it. In face of a structural liquidity surplus, the RF Central Bank will no longer be able to rely on this lever while steering the money market interest rate, even if it manages to absorb excessive liquidity (liquidity in excess of the banking sector's actual need for liquidity determined by autonomous liquidity factors and the rules for requires reserves).

In the presence of a structural liquidity surplus, the short-term money market interest rate usually hovers in the lower half of the interest rate corridor, most often near its lower border. In Russia, it typically behaved like this during the periods of structural liquidity surplus (prior to the 2008 financial crisis and over the period $2010-032011$ ). This happens not because there is 'too much' liquidity (excessive liquidity can be absorbed), but because banks obtain liquidity relatively cheap - that is, at rates smaller than the key rate. Efficient control over the market interest rate can be restored by means of switching over from the corridor system to the floor system. However, such a shift in the interest rate policy can be feasible only when it can be expected that structural liquidity will remain in surplus for a sufficiently long period of time.

Another unpleasant phenomenon is the changeability of the banking sector's structural liquidity position, especially in the situation when it is fluctuating back and forth from deficit to surplus around the zero point. Therefore, the Bank of Russia's paramount goals in this respect are as follows: to ensure the maximum possible stability in the behavior of the banking sector's structural liquidity position and to most accurately forecast its future dynamics. A decisive role in achieving the first goal can be played by the RF Ministry of Finance if it ensures a very even movement of funds in the general government accounts with the Bank of Russia (in particular, by placing the temporarily free budget funds as deposits with credit institutions).

It should be noted that one more serious problem that has arisen in connection with the structural liquidity surplus is that the significant costs associated with the RF Central Bank's liquidity absorption operations significantly reduce the CB's profit, and even may make it negative.

In 2016, problems in the management of the money market interest rate in Russia will certainly crop up before the banking sector begins to display a structural liquidity surplus in a full sense of that word. The amount of banking sector's repo debt to the Bank of Russia is rapidly shrinking (Fig. 1). Most probably, banks will be reducing their repo debt to the Bank of Russia at a faster rate than their debt against loans secured by non-marketable assets. 


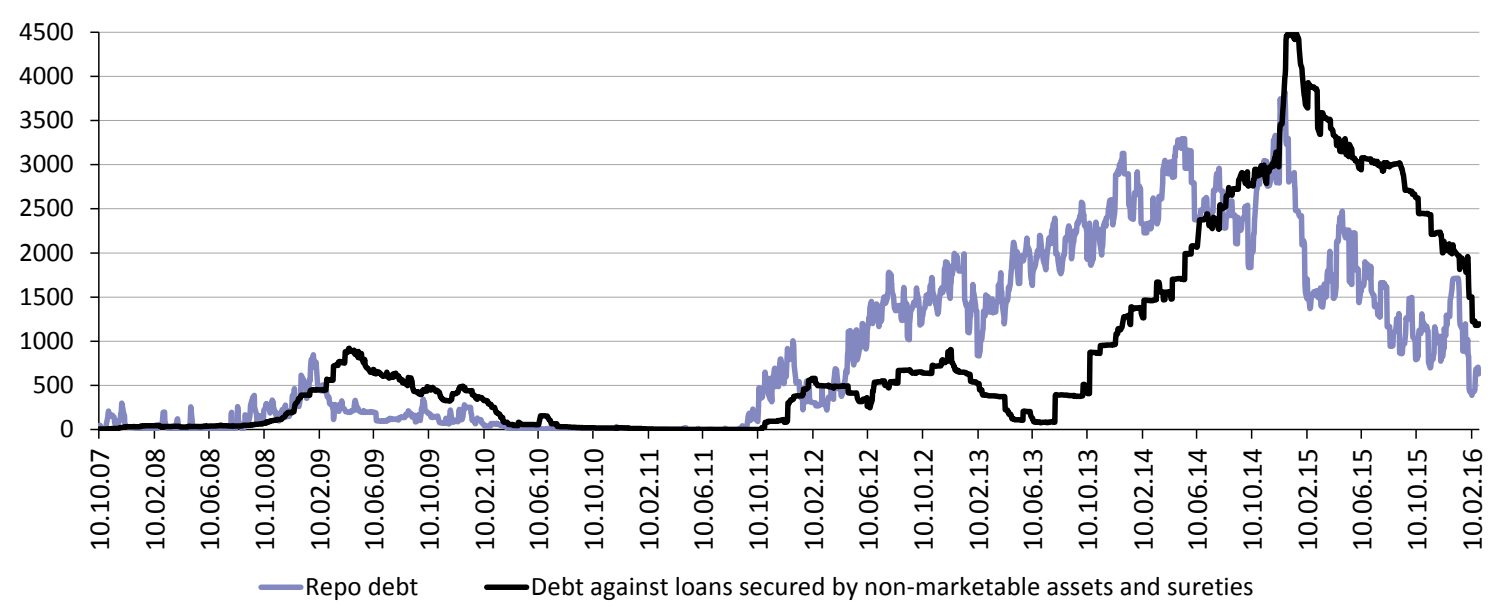

Source: Bank of Russia.

Fig. 1. The Amount of Credit Institutions' Debt to the Bank of Russia against Repo Loans and Loans Secured by Non-marketable Assets and Sureties Over Period 2007 - February 2016

The amount of repo debt of credit institutions as of 20 February 2016 amounted to a mere $\mathrm{Rb} 0.7$ trillion. The amount of debt against loans secured by non-marketable assets and sureties was markedly higher - Rb 1.8 trillion. It is noteworthy that the amount of debt against loans issued for a term of 181 to 365 days was $\mathrm{Rb} 0.5$ trillion, that against loans issued for a term over 365 days - Rb 0.2 trillion. Quite probably, the amount of the banking sector's repo debt will dwindle to zero before its debt against loans secured by non-marketable assets and sureties dwindles to zero. The short-term money market interest rate will thus be deprived of the steering effects of the Bank of Russia's main operations (repo auctions).

Structural liquidity surplus in the banking sector should be avoided in order to efficiently navigate the short-term money market interest rate and to properly control the inflation rate. The Bank of Russia can prevent the shrinkage of structural liquidity deficit and turning into surplus by selling assets from its balance sheet. Such a possibility (and the backing for it) can be provided by the RF Ministry of Finance's operations aimed at covering federal budget deficit by the monies from sovereign funds denominated in foreign currencies and kept in its accounts with the Bank of Russia. The sale of foreign currency by the Bank of Russia in the domestic market must follow the exchange of the aforesaid funds into rubles by the RF Ministry of Finance.

The Bank of Russia must also continue to improve the mechanisms applied in its interest rate policy, in particularly the symmetric interest rate corridor. The limit on market operations for one-week repo auctions is set by the Bank of Russia with upward or downward deviations (sometimes considerable) from the weekly forecasts of the banking sector's liquidity factors. The results of one-week repo auctions often demonstrate that the cut-off rate (and the average weighted repo rate) is set at a level noticeably higher than the floor rate (the key rate). At the same time, banks are offered substantial liquidity volumes in the framework of standing facilities (at a higher rate), while they also hold hefty sums as deposits with the Bank of Russia.

The above observations have led us to the following conclusions. The Bank of Russia issues its forecasts of the behavior of liquidity factors (first of all, autonomous liquidity factors) with significant errors. Its weekly (and even daily) forecasts of the banking sector's demand for reserves (the mon- 
ies in correspondent accounts) are very inaccurate. The financial intermediary services in the interbank lending market are underdeveloped, and the market itself is fragmentary. As a result, substantial sums borrowed by credit institutions from the Bank of Russia as standing facilities coexist with their voluminous deposits with the Bank of Russia. The banks that experience a temporary shortage of reserves do not borrow from those banks that have a surplus of reserves.

The activity level displayed by credit institutions in the interbank lending market depends, among other things, on the width of the interest rate corridor for the central bank's operations. The wider the corridor, the more prominent the intermediary role of credit institutions, and the smaller the central bank's role. And vice versa, a narrow interest rate corridor results in a shift of the intermediary functions towards the central bank. This is the first argument in favor of establishing a wider interest rate corridor in Russia, where both the transaction costs and the credit risks in the interbank lending market are high. The second argument relies on the desirability of damping the effects of short-term (transitory) external shocks on the ruble's exchange rate. In response to a downward pressure on the ruble's exchange rate the short-term money market interest rate will rise towards the upper border of the interest rate corridor, while in response to the ruble's strengthening it will decline towards its lower border. The fluctuations of the interest rate ease the speculating fluctuations of capital inflow and/or outflow.

In view of the aforesaid conclusions, we may offer the following proposals.

The Bank of Russia should upgrade its forecast of the behavior of the banking sector's structural liquidity deficit for 2016, with due regard for the increased rate of its decline. The Bank of Russia's balance sheet should be released in a more detailed format, so as to make it possible for experts to analyze the banking sector's liquidity indices and the monetary policy tools applied by the Bank of Russia. The balance sheet should display (a) the components of the cash inflows in the general government accounts and other autonomous liquidity factors, (b) the results of the Bank of Russia's liquidity provision and absorption operations relative to its monetary policy tools, (c) the amount of money kept in the correspondent accounts with credit institutions. The Bank of Russia's balance sheet should be published once a week.

The rule should be set whereby the Bank of Russia should be obliged to sell foreign currency in the domestic forex market whenever the RF Ministry of Finance comes to the decision that some of its funds denominated in foreign currencies and kept in its accounts with the Bank of Russia should be converted into rubles. In this connection, the Bank of Russia should conduct such trading operations in a commercially reasonable manner (to sell a given foreign currency when its exchange rate is on the rise), without resorting to foreign exchange rate targeting.

The other goals are as follows: to complete the switchover to the required reserves averaging mechanism; to raise the reserves averaging coefficient to 1 , to significantly increase the number of credit institutions endowed with the right of reserves averaging; to consider the possibility of widening the interest rate corridor for the Bank of Russia's operations in order to boost activity in the interbank lending market. 